\title{
Co-immobilization and stabilization of xylanase, $\beta$-xylosidase and $\alpha$-L-arabinofuranosidase from Penicillium janczewskii for arabinoxylan hydrolysis
}

\author{
César Rafael Fanchini Terrasan ${ }^{\mathrm{a}, *}$, Lara Trobo-Maseda ${ }^{\mathrm{a}}$, Sonia Moreno-Pérez ${ }^{\mathrm{a}}$, \\ Eleonora Cano Carmona ${ }^{b}$, Benevides Costa Pessela ${ }^{c}$, José Manuel Guisan ${ }^{a}$ \\ a Departamento de Biocatálisis, Instituto de Catálisis y Petroleoquimica (ICP), Consejo Superior de Investigaciones Científicas (CSIC), Campus Universidad \\ Autónoma de Madrid (UAM), Cantoblanco, 28049 Madrid, Spain \\ ${ }^{\mathrm{b}}$ Biochemistry and Microbiology Department, Biosciences Institute, Univ. Estadual Paulista-UNESP, PO 199, 13506-900 Rio Claro, SP, Brazil \\ ${ }^{\mathrm{c}}$ Departamento de Biotecnología y Microbiología de Alimentos, Instituto de Investigación en Ciencias de los Alimentos (CIAL), Consejo Superior de \\ Investigaciones Científicas (CSIC), Campus Universidad Autónoma de Madrid (UAM), Cantoblanco, 28049 Madrid, Spain
}

\section{A R T I C L E I N F O}

\section{Article history:}

Received 30 November 2015

Received in revised form 23 February 2016

Accepted 25 February 2016

Available online 3 March 2016

\section{Keywords:}

Penicillium janczewskii

Xylanase

$\beta$-xylosidase

$\alpha$-L-arabinofuranosidase

Enzyme co-immobilization

Xylan hydrolysis

\begin{abstract}
A B S T R A C T
Differently activated agarose-based supports were evaluated for co-immobilization of a crude extract from Penicillium janczewskii containing xylanase, $\beta$-xylosidase and $\alpha$-L-arabinofuranosidase activities Adequately selecting support and immobilization conditions ( $8 \mathrm{~h}$, using agarose with $10 \%$ crosslinking) increased enzyme levels substantially, mainly in relation to the xylanase (2-fold). A coating with dextran aldehyde MW $6000 \mathrm{Da}$, partially oxidized, covalently attached the enzymes to the support. Optimum activity was verified in the $\mathrm{pH}$ range $2-4$, and at 50,65 and $80^{\circ} \mathrm{C}$ for the xylanase, $\alpha$-L-arabinofuranosidase and $\beta$-xylosidase, respectively. The xylanase was highly thermostable retaining more than $70 \%$ of activity even after $24 \mathrm{~h}$ incubation at 60 and $70^{\circ} \mathrm{C}$; and at $80^{\circ} \mathrm{C}$ its half-life was $1.7 \mathrm{~h}$. The half-lives of the $\beta$ xylosidase and $\alpha$-L-arabinofuranosidase at $50{ }^{\circ} \mathrm{C}$ were 2.3 and $3.8 \mathrm{~h}$, respectively. The co-immobilization of the enzymes on a single support give raise to a functional multi-enzymatic biocatalyst acting in the complete hydrolysis of different and complex substrates such as oat spelt and wheat arabinoxylans, with xylose yield higher than $40 \%$. The xylanase and the $\alpha$-L-arabinofuranosidase presented high stability retaining 86.6 and $88.0 \%$ of activity after 10 reuse cycles.
\end{abstract}

(C) 2016 Elsevier Ltd. All rights reserved.

\section{Introduction}

Xylan is the second most abundant biopolymer in plant cell walls and the main hemicellulosic polysaccharide. It is composed of a $\beta$ - $(1 \rightarrow 4)$ D-xylopyranosyl backbone substituted at various degrees by side chain residues such as glucopyranosyl, 4-O-methyl-D-glucurono-pyranosyl, $\alpha$-L-arabinofuranosyl, acetyl, feruloyl, and/or p-coumaroyl [1]. The precise composition of the polymer is strongly dependent on plant species and tissue. For instance, hard wood xylans often have D-glucuronic acid attached

\footnotetext{
* Corresponding author at: Departamento de Biocatálisis, Instituto de Catálisis y Petroleoquimica (ICP), Consejo Superior de Investigaciones Científicas (CSIC), Campus Universidad Autónoma de Madrid (UAM), Cantoblanco, Calle de Marie Curie, 28049 Madrid, Spain.

E-mail addresses: cesarterrasan@hotmail.com, cesarterrasan@gmail.com (C.R. Fanchini Terrasan).
}

to their backbone, whereas L-arabinose is the most common branch in cereal xylans [2].

Given the diversity of xylan structures, their complete and efficient hydrolysis involves the synergistic action of main chain degrading enzymes, including endo- $\beta-1,4$-xylanases (EC 3.2.1.8) and $\beta$-D-xylosidases (EC 3.2.1.37), and side chain cleaving enzymes, including $\alpha$-L-arabinofuranosidases (EC 3.2.1.55), $\alpha$-glucuronidases (EC 3.2.1.139), acetyl xylan esterase (EC 3.1.1.72), and feruloyl esterases (EC 3.1.1.73). Endo- $\beta-1,4$-xylanase and $\beta$-Dxylosidase are the main enzymes responsible for the degradation of the polymer: xylanases cleave the internal $\beta-(1 \rightarrow 4)$ bonds in the xylan backbone, liberating different chain-length-(substituted) xylooligosaccharides, and $\beta$-xylosidases are exoglycosidases that release xylose from the non-reducing ends of these xylooligosaccharides. $\beta$-xylosidases are critical for the systems since they carry the greatest work load in terms of number of glycosidic bonds cleaved, as well as in relieving product inhibition of xylanases [3]. Among other accessory enzymes, $\alpha$-L-arabinofuranosidases are 
exo-type enzymes that catalyze the cleavage of the terminal $\alpha$-Larabinofuranosyl residues from arabinosylated substrates. Xylan hydrolysis is not aleatory, i.e., the degree of substitution in xylan influence the products of hydrolysis for xylanases [4]. In this sense, accessory enzymes such as $\alpha$-L-arabinofuranosidases are important since the removal of side-chain residues from xylan backbone may have a synergistic effect with the other xylanolytic enzymes [5] and also the difference in substrate specificity among different xylanases has important implications in the deconstruction of xylan [4].

Enzyme immobilization poses as a possibility to improve the characteristics of an enzyme in terms of stability and catalysis, as well as for process improvement allowing the reuse of the biocatalyst for many operational cycles [6]. Immobilization of more than one enzyme on the same support, however, is especially challenging, as it has to preserve the catalytic activity of all enzymes involved in the system and ideally improve their stability [7]. Many xylanolytic enzymes have been individually immobilized by different methods; and some studies have investigated the coimmobilization of two xylanolytic enzymes [8]. In this sense, the xylanase and $\beta$-xylosidase from Talaromyces thermophilus were co-immobilized on chitosan and employed for the hydrolysis of oat spelt xylan, demonstrating the synergistic action of both enzymes by increasing the saccharification of the substrate [9]. In another study, co-immobilization of recombinant xylanase and $\alpha$ L-arabinofuranosidase onglyoxyl agarose was evaluated through different approaches in the hydrolysis of arabinoxylan [10]. The effect of xylanase, $\beta$-xylosidase and $\alpha$-L-arabinofuranosidase from Aspergillus oryzae in the decomposition of arabinoxylan was verified using the soluble enzymes in the moromi mash during soy sauce fermentation [11], nevertheless, co-immobilization of three xylanolytic enzymes acting cooperatively in the complete hydrolysis of complex substrates has not been reported to date.

This way, the aims of this work were to establish a protocol for simultaneous co-immobilization of the xylanase, $\beta$-xylosidase and $\alpha$-L-arabinofuranosidase from Penicillium janczewskii present in the crude extracellular extract, as well as improve the stabilization of the immobilized enzymes via post-immobilization techniques. After that, the immobilized enzymes were biochemically characterized and evaluated in the hydrolysis of arabinoxylans.

\section{Materials and methods}

\subsection{Materials}

Agarose with 4, 6 and $10 \%$ of cross-linking BCL were purchased from Agarose Bead Technologies (Madrid, Spain). $p$-nitrophenyl $\beta$-D-xylopyranoside ( $p N P X)$, glycidol, potassium tetraborate tetrahydrate, sodium borohydride, sodium periodate, ethylenediamine, glutaraldehyde, Leuconostocc spp. dextran (MW 6000-100,000), polyethylenimine (PEI, MW 1300), oat spelt and beechwood xylans were obtained from Sigma-Aldrich Co (St. Louis, MO). D-xylose Assay Kit, xylose, $p$-nitrophenyl $\alpha$-Larabinofuranoside ( $p$ NPAra) and low viscosity wheat arabinoxylan were from Megazyme (Wicklow, Ireland). All reagents were of analytical grade.

\subsection{Methods}

\subsubsection{Microorganism, enzyme production and preparation of enzyme extract}

P. janczewskii (CRM 1348) is deposited in The Central of Microbial Resources, CMR-UNESP, Brazil. The microorganism was maintained on Vogel solid medium [12] and liquid cultures were prepared in the same medium with brewer's spent grain as substrate, under optimized conditions for xylanolytic enzymes production [13]. After cultivation, the mycelium was removed by vacuum filtration and the culture filtrate was centrifuged $(10,000 \mathrm{~g}$, $4^{\circ} \mathrm{C}, 15 \mathrm{~min}$ ). The supernatant was dialyzed overnight against distilled water, $0.025 \mathrm{M}$ sodium acetate buffer $\mathrm{pH} 5.0$ or $0.025 \mathrm{M}$ sodium phosphate buffer $\mathrm{pH} 7.0$ before immobilization. A sample of the supernatant was also treated with $0.01 \mathrm{M}$ sodium periodate for $1.5 \mathrm{~h}$ in order to oxidize sugar moieties of the enzymes and then dialyzed against $0.025 \mathrm{M}$ sodium phosphate buffer $\mathrm{pH}$ 7.0.

\subsection{2. $S D S-P A G E$}

A sample containing $50 \mu \mathrm{g}$ of protein prepared from the extracellular extract obtained under optimized conditions for xylanase production (medium with oat spelt xylan, $\mathrm{pH} 6.5,7$ days of cultivation, $\left.30^{\circ} \mathrm{C}\right)$ was applied to SDS-PAGE performed in $8-18 \%(\mathrm{w} / \mathrm{v})$ gradient gels, according to Laemmli [14]. The resolved protein bands were visualized after staining with $0.1 \%$ Coomassie brilliant blue R-250 dissolved in methanol, acetic acid, and distilled water $(4: 1: 5 \mathrm{v} / \mathrm{v} / \mathrm{v})$. Standard proteins (Sigma) were phosphorylase b (97 kDa), bovine serum albumin (66 kDa), ovalbumin (45 kDa), carbonic anhydrase (29kDa), trypsin inhibitor (20kDa), and $\alpha$ lactalbumin (14.2 kDa).

\subsubsection{Enzyme assays}

Xylanase activity was determined according to Bailey et al. [15] with $1 \%(\mathrm{w} / \mathrm{v})$ beechwood xylan prepared in $0.05 \mathrm{M}$ sodium acetate buffer $\mathrm{pH} 5.0$ (before determining optimum $\mathrm{pH}$ ) or $\mathrm{pH}$ 4.0 (after determining optimum $\mathrm{pH}$ ) and appropriately diluted enzyme solution. Reducing sugars were quantified with DNS acid reagent [16]. $\beta$-xylosidase and $\alpha$-L-arabinofuranosidase activities were determined in a reaction mixture containing, respectively, $3 \mathrm{mM} p N P X$ and $p N P A r a$ prepared in $0.05 \mathrm{M}$ sodium acetate buffer pH 5.0 (before determining optimum $\mathrm{pH}$ ) or $\mathrm{pH} 4.0$ (after determining optimum $\mathrm{pH}$ ) and appropriately diluted enzyme solution to $1 \mathrm{~mL}$ final volume. Reactions were stopped by adding $1 \mathrm{~mL}$ of a saturated potassium tetraborate solution and the absorbance was measured at $405 \mathrm{~nm}$ [17]. One unit of activity was defined as the amount of enzyme required to release $1 \mu \mathrm{mol}$ of product equivalent per min in the assay conditions at $25^{\circ} \mathrm{C}$.

\subsubsection{Preparation of support}

Monoaminoethyl- $N$-aminoethyl (MANAE)-agarose, was prepared as described elsewhere [18] and the glutaraldehyde-agarose support was prepared from MANAE agarose [19,20]. Briefly described, we used $10 \mathrm{~g}$ of MANAE in $20 \mathrm{~mL}$ of 0.5 or $15 \%(\mathrm{v} / \mathrm{v})$ glutaraldehyde solution prepared in $0.2 \mathrm{M}$ phosphate buffer $\mathrm{pH} 7.0$. The suspensions were kept under mild stirring at $25^{\circ} \mathrm{C}$ for 1 and $15 \mathrm{~h}$ in the case of the supports activated with 0.5 or $15 \%(\mathrm{v} / \mathrm{v})$ glutaraldehyde, respectively. This treatment permitted to fully modify the primary amino groups of the support with one or two glutaraldehyde molecules, respectively [19]. After that, the supports were filtered and washed exhaustively with $0.025 \mathrm{M}$ sodium phosphate buffer and then with distilled water. Glyoxyl-agarose was prepared with the maximal activation degree, as previously described [21]. Polyethylenimine (PEI) and dextran sulfate [22] and heterofunctional amino-glyoxyl and amino-epoxide [23,24] supports were prepared as described elsewhere.

The supports were initially prepared using agarose with $4 \%$ crosslinking. MANAE and $0.5 \%(\mathrm{w} / \mathrm{v})$ glutaraldehyde supports were further prepared using agarose with 6 and 10\% crosslinking. Activated supports were stored at $4{ }^{\circ} \mathrm{C}$ and, before use, washed with incubation buffer according to immobilization condition.

\subsubsection{Enzyme immobilization}

Immobilizations were performed by suspending $1: 10(\mathrm{w} / \mathrm{v})$ the activated supports in the dialyzed/diluted enzyme solution. Buffers 
for each immobilization were: $0.025 \mathrm{M}$ sodium phosphate buffer pH 7.0 for MANAE, PEI, glutaraldehyde, amino-epoxide and aminoglyoxyl supports, $0.05 \mathrm{M}$ sodium acetate buffer $\mathrm{pH} 5.0$ for dextran sulfate support, $0.1 \mathrm{M}$ sodium bicarbonate buffer $\mathrm{pH} 10.0$ for glyoxyl support (enzyme solution dialyzed against distilled water was 2 -fold diluted in the buffer). Immobilizations were carried out under gentle agitation at $25^{\circ} \mathrm{C}$ for $4 \mathrm{~h}$ or overnight incubation. During immobilization, samples of the suspensions and the supernatants were withdrawn and enzyme activities were measured. Proteins were measured during immobilization time-course and immobilization for different periods.

\subsubsection{Post-immobilization techniques}

Dextran-coated derivatives: a mass of $0.5 \mathrm{~g}$ of the uncoated glutaraldehyde (Glut) derivative (immobilization carried out by $8 \mathrm{~h}$ ) was added to $5 \mathrm{~mL}$ of aldehyde-dextran suspensions, $\mathrm{pH}$ adjusted to 7.0. Dextrans with MW of $1500,6000,25,000$ and $75,000 \mathrm{Da}$ completely oxidized were initially evaluated [25]. Dextran with MW of 6000 with 20 and $40 \%$ degree of oxidation were further evaluated. The suspensions were gently agitated overnight, the derivative was then re-suspended in sodium borate buffer $\mathrm{pH}$ 8.5 or sodium phosphate buffer $\mathrm{pH} 7.0$ and reduced by adding $1 \mathrm{mg} / \mathrm{mL}$ sodium borohydride. The suspension was gently agitated for $30 \mathrm{~min}$, washed abundantly with water and vacuum filtered.

PEI-coated derivative: a mass of $0.5 \mathrm{~g}$ of the uncoated Glut derivative (immobilization carried out for $8 \mathrm{~h}$ ) was added to $5 \mathrm{~mL}$ of 5\% (w/v) PEI MW 1300 Da solution, pH was adjusted to 7.0. The suspension was gently agitated overnight, washed abundantly with water and vacuum filtered.

Glutaraldehyde cross-linked derivative: a mass of $1.0 \mathrm{~g}$ of the uncoated Glut derivative (immobilization carried out for $8 \mathrm{~h}$ ) was added to $10 \mathrm{~mL}$ of $0.5 \%(\mathrm{v} / \mathrm{v})$ glutaraldehyde solution $\mathrm{pH}$ adjusted to 7.0. The suspensions were gently agitated for $30 \mathrm{~min}$, washed abundantly with water and vacuum filtered. A mass of $0.5 \mathrm{~g}$ of this derivative was directly reduced with $1 \mathrm{mg} / \mathrm{mL}$ sodium borohydride and $0.5 \mathrm{~g}$ was previously coated with dextran, as described above, and then reduced with $1 \mathrm{mg} / \mathrm{mL}$ sodium borohydride. The suspensions were washed abundantly with water and vacuum filtered.

\subsubsection{Immobilization parameters}

Immobilization yield was defined as the ratio between the activities (or protein) in the supernatant compared to the activity (or protein) in the control. Expressed activity was defined as the ratio of the activity in the final suspension after the immobilization process and the initial enzyme activity.

\subsubsection{Evaluation of the attachment between enzyme and support}

The glutaraldehyde agarose $10 \mathrm{BCL}$ derivative (before and after coating with aldehyde dextran) was incubated in $0.005 \mathrm{M}$ sodium phosphate buffer pH 7.0 with $0.5 \mathrm{M} \mathrm{NaCl}$ at $25^{\circ} \mathrm{C}$. After $1 \mathrm{~h}$, enzyme activities were analyzed in the supernatant, as previously described.

\subsubsection{Derivative characterization}

2.2.9.1. Thermal stability. A mass of $0.1 \mathrm{~g}$ of the Glut derivative coated with dextran MW 6000 and $40 \%$ oxidation degree was suspended in $1.0 \mathrm{~mL}$ of $0.05 \mathrm{M}$ acetate buffer $\mathrm{pH} 5.0$ and incubated at $50^{\circ} \mathrm{C}$. In all cases, samples of the suspension were withdrawn at several intervals and the activity was assayed as previously described. Residual activity was calculated as the ratio between activity at a given time and the activity in the beginning of incubation (regarded as 100\%).

2.2.9.2. $\mathrm{pH}$ stability. A mass of $0.1 \mathrm{~g}$ of the Glut derivative coated with dextran MW 6000 at $40 \%$ degree of oxidation was suspended in $1.0 \mathrm{~mL}$ of $0.05 \mathrm{M}$ glycine $\mathrm{HCl}$ buffer $\mathrm{pH} 3.0,0.05 \mathrm{M}$ sodium acetate buffer $\mathrm{pH} 4.0$ and 5.0, and $0.05 \mathrm{M}$ sodium phosphate buffer $\mathrm{pH} 7.0$. The suspension was incubated at $50^{\circ} \mathrm{C}$ and after $4 \mathrm{~h}$ residual activity was assayed. Initial activities before incubation were regarded as $100 \%$.

2.2.9.3. Optima $\mathrm{pH}$ and temperature. Optimum $\mathrm{pH}$ was determined by assaying enzyme activities of the Glut derivative coated with dextran MW 6000 at $40 \%$ degree of oxidation at $25^{\circ} \mathrm{C}$ at various $\mathrm{pH}$ from 2.0 to 8.0. The following buffers were utilized: $0.05 \mathrm{M}$ glycine$\mathrm{HCl} \mathrm{pH} 2.0$ and 3.0, 0.05 $\mathrm{M}$ sodium acetate $\mathrm{pH} 4.0$ and $5.0,0.05 \mathrm{M}$ sodium phosphate $\mathrm{pH} 6.2$ and 7.0, and $0.05 \mathrm{M}$ Tris $\mathrm{HCl} \mathrm{pH} 8.0$.

Optimum temperature was determined by assaying enzyme activities at temperatures ranging from 40 to $85^{\circ} \mathrm{C}$, with $5^{\circ} \mathrm{C}$ intervals, in $0.05 \mathrm{M}$ sodium acetate buffer $\mathrm{pH}$ 5.0.

\subsubsection{Hydrolysis of arabinoxylans}

The hydrolysis of $0.5 \%(\mathrm{w} / \mathrm{v})$ oat spelt xylan (arabinose residues $\leq 10 \%$, glucose residues $\leq 15 \%$, xylose residues $\geq 70 \%$ ) and low viscosity wheat arabinoxylan (38/62 arabinose:xylose relation) were carried using the Glut derivative coated with dextran MW 6000 at $40 \%$ degree of oxidation. The reactions were carried out in $0.05 \mathrm{M}$ sodium acetate buffer $\mathrm{pH} 4.0$ at $40^{\circ} \mathrm{C}$. Collected samples were filtered and the adequately diluted supernatant was analyzed for xylose.

\subsubsection{Reuse assay}

Successive hydrolysis cycles of $0.5 \%(\mathrm{w} / \mathrm{v})$ wheat arabinoxylan prepared in $0.05 \mathrm{M}$ sodium acetate buffer $\mathrm{pH} 4.0$ were performed using the Glut derivative coated with dextran MW 6000 at $40 \%$ degree of oxidation, at 1:10 proportion $(\mathrm{w} / \mathrm{v})$. Each cycle was carried out at $40^{\circ} \mathrm{C}$ for $1 \mathrm{~h}$ under magnetic stirring (300 rpm). At the end of the cycles, the derivative was filtered, washed with $0.05 \mathrm{M}$ sodium acetate buffer $\mathrm{pH} 4.0$ and new substrate was added for a new reaction round. Samples of the supernatant were withdrawn during the first, the fifth and the tenth cycles, filtered and analyzed for reducing sugars. After the fifth and the tenth cycles the derivative was suspended in the washing buffer $(1: 10, w / v)$ and residual activities were measured, as previously described (activities before the first cycle were regarded as $100 \%$ ).

\subsubsection{Analytical methods}

Protein concentration was determined with the modified Bradford's method, with bovine serum albumin as standard [26]. Reducing sugars were quantified with DNS acid reagent, with xylose as standard [16]. Xylose was quantified using the enzymatic $D$-xylose Assay Kit. The first reaction involves the conversion of the $\alpha$ - to the $\beta$-anomeric form of D-xylose catalyzed by xylose mutarotase. The $\beta$-D-xylose was then oxidized by $\mathrm{NAD}^{+}$to $\mathrm{D}$-xylonic acid in the presence of $\beta$-xylose dehydrogenase. The amount of NADH formed in the reaction is stoichiometric with the amount of D-xylose. NADH was measured by the increase in absorbance at $340 \mathrm{~nm}\left(\varepsilon=6300 \mathrm{M}^{-1} \mathrm{~cm}^{-1}\right)$. Samples of hydrolyzed oat spelt and wheat arabinoxylans were adequately diluted and analyzed according to the supplier instruction, in duplicate, and expressed as mean value. Xylose yield was calculated using 0.88 as the conversion factor of pentose to equivalent xylan, as below:

Xylose yield $(\%)=\frac{\text { xylose released }(g) \times 0.88}{\text { initial xylan }(g)} \times 100$

\section{Results and discussion}

\subsection{Enzyme immobilization}

P. janczewskii was isolated from soil of the Brazilian Rainforest [27] and characterized as an excellent producer of xylanolytic 
Table 1

Co-immobilization of xylanase, $\beta$-xylosidase and $\alpha$-L-arabinofuranosidase from P. janczewskii on different agarose-based supports.

\begin{tabular}{|c|c|c|c|c|c|c|c|}
\hline \multirow[t]{2}{*}{ Derivative } & \multirow[t]{2}{*}{ Condition/strategy } & \multicolumn{2}{|l|}{ Xylanase } & \multicolumn{2}{|c|}{$\beta$-xylosidase } & \multicolumn{2}{|c|}{$\alpha$-L-arabinofuranosidase } \\
\hline & & Yield (\%) & Expressed activity (\%) & Yield (\%) & Expressed activity (\%) & Yield(\%) & Expressed activity (\%) \\
\hline \multirow[t]{3}{*}{ MANAE } & $\mathrm{pH} 7,4 \mathrm{~h}$ & 53.4 & 20.0 & 100 & 58.5 & 100 & 18.0 \\
\hline & pH 8.5 , overnight & - & - & - & - & - & - \\
\hline & $\mathrm{pH} 7,24 \mathrm{~h}$, sodium periodate treatment & 100 & 167.5 & 100 & 73.3 & 100 & 55.1 \\
\hline Glutaraldehyde $0.5 \%$ & $\mathrm{pH} 7,4 \mathrm{~h}$ & 63.2 & 20.8 & 100 & 76.2 & 100 & 22.4 \\
\hline Glutaraldehyde $10 \%$ & $\mathrm{pH} 7,4 \mathrm{~h}$ & 100 & 1.2 & 100 & 100 & 100 & 74 \\
\hline PEI 1300 0,5\% & pH 7, overnight & 100 & 6.8 & 0 & 0 & 30 & 28.9 \\
\hline
\end{tabular}

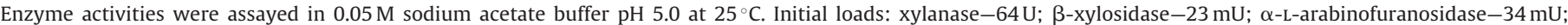
proteins $-5.3 \mathrm{mg}$. Supports were prepared using agarose with $4 \%$ crosslinking.

Table 2

Co-immobilization of xylanase, $\beta$-xylosidase and $\alpha$-L-arabinofuranosidase from P. janczewskii on different agarose beads MANAE and Glut supports.

\begin{tabular}{|c|c|c|c|c|}
\hline \multirow[t]{2}{*}{ Derivative } & \multirow[t]{2}{*}{ Agarose beads (\% CL) } & \multicolumn{3}{|c|}{ Expressed activity (\%) } \\
\hline & & Xylanase & $\beta$-xylosidase & $\alpha$-L-arabinofuranosidase \\
\hline \multirow[t]{3}{*}{ MANAE } & 4 & 20.0 & 58.5 & 18.0 \\
\hline & 6 & 14.6 & 54.6 & 14.2 \\
\hline & 10 & 14.0 & 54.0 & 14.0 \\
\hline \multirow[t]{3}{*}{ Glut } & 4 & 20.8 & 76.2 & 22.4 \\
\hline & 6 & 23.1 & 82.5 & 25.1 \\
\hline & 10 & 26.1 & 100 & 42.5 \\
\hline
\end{tabular}

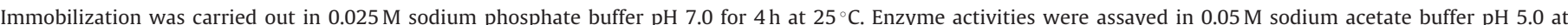

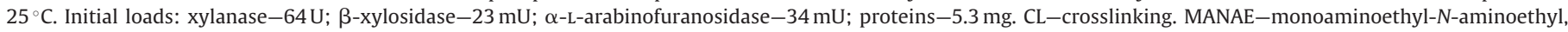
Glut $-0.5 \%(\mathrm{v} / \mathrm{v})$ glutaraldehyde activated support.

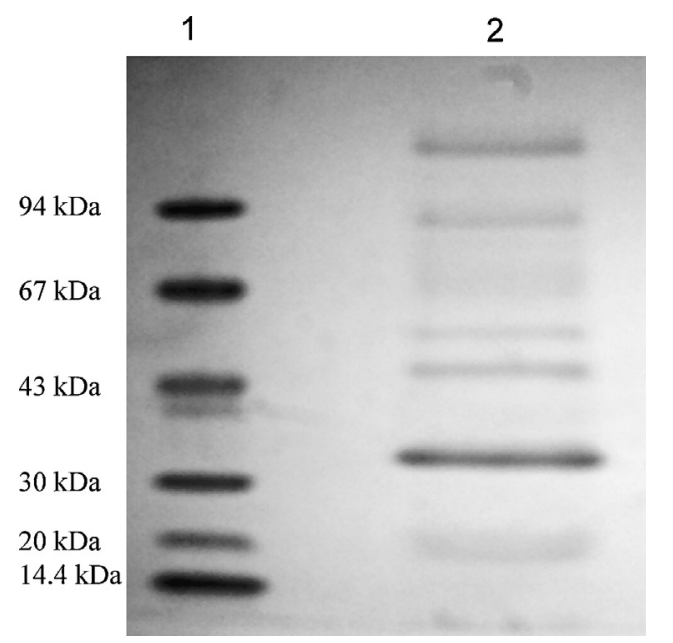

Fig. 1. SDS-PAGE (8-18\%) of the crude extracellular extract from $P$. janczewskii. Lane 1: standard proteins, phosphorylase b $(94 \mathrm{kDa})$, bovine serum albumin $(67 \mathrm{kDa})$, ovalbumin (43 kDa), carbonic anhydrase (30 kDa), trypsin inhibitor (20 kDa) and $\alpha$ lactalbumin $(14.4 \mathrm{kDa})$; Lane 2: crude extracellular extract $(50 \mu \mathrm{g})$. Modified from [28].

enzymes in the absence of cellulases [13]. Production of xylanase, $\beta$-xylosidase and $\alpha$-L-arabinofuranosidase has been previously optimized $[28,29]$ but other enzymes from the xylanolytic complex may also be produced by this fungal strain since SDS-PAGE revealed the presence of several extracellular proteins (Fig. 1) [28]. Due to their potential application in many bioprocesses, several activation protocols, techniques and strategies were evaluated in order to optimize the concomitant immobilization of the crude extracellular xylanase, $\beta$-xylosidase and $\alpha$-L-arabinofuranosidase on agarosebased supports, which have been widely used for immobilizing different enzymes [30].

In general, good results were observed in relation to the $\beta$-xylosidase immobilization, although the xylanase and the $\alpha$ L-arabinofuranosidase were hardly immobilized on the supports (Table 1). Good balance for the immobilization of the three enzymes was obtained with ionic immobilization on MANAE agarose. The use of $\mathrm{pH} 8.5$ and more prolonged immobilization period did not improve the activities on this support. When the enzymes were previously treated with sodium periodate to oxidize saccharide moieties of the proteins, the three enzymes were easily attached to the anionic MANAE support. This fact indicate that the presence of carbohydrates may be blocking the access of the enzymes to the reactive groups of the support or the formed aldehyde can readily react with these groups forming imine or Schiff bases. The removal of glycosylation was good in terms of immobilization; nevertheless, the enzymes became unstable even during mild conditions of enzymatic assays (not shown). The use of MANAE agarose cross-linked with $0.5 \%(\mathrm{w} / \mathrm{v})$ glutaraldehyde also resulted in good enzyme immobilization. When this support was activated with higher glutaraldehyde concentration (10\%, $\mathrm{w} / \mathrm{v}$ ), which results in the formation of glutaraldehyde dimers, improved immobilization yield of the xylanase was observed, probable consequence of the higher glutaraldehyde concentration, which allowed more attachments between enzyme and support. Nevertheless, these attachments may have been excessive, causing distortion in the xylanase structure resulting in the very low expressed activity. Expressed activities of the $\beta$-xylosidase and $\alpha$-L-arabinofuranosidase increased by increasing glutaraldehyde concentration that may be related to the fact that these enzymes usually have higher MW than the xylanases or correspond to multimeric enzymes $[31,32]$. In this case, the higher glutaraldehyde concentration provided more attachments stabilizing the structure of the immobilized enzyme or provided enough attachments to stabilize all enzyme subunits, thus resulting in the higher expressed activity. Immobilization of enzymes on glutaraldehyde-activated supports has been largely used on supports previously activated with amine groups. Immobilization is promoted through a twostep mechanism: in a first step the enzyme is adsorbed on the support via an anionic exchange mechanism and then, the covalent immobilization occurs [20,33].

The enzymes could not be immobilized on PEI (Table 1), dextran sulfate and glyoxyl activated supports (not shown). In the case of glyoxyl support, the enzymes probably present low stability in $\mathrm{pH}$ 
Table 3

Co-immobilization of xylanase, $\beta$-xylosidase and $\alpha$-L-arabinofuranosidase from P. janczewskii for different periods on Glut agarose $10 \%$ crosslinking.

\begin{tabular}{|c|c|c|c|c|c|c|c|}
\hline \multirow[t]{2}{*}{ Incubation (h) } & \multirow[t]{2}{*}{ Protein yield (\%) } & \multicolumn{2}{|l|}{ Xylanase } & \multicolumn{2}{|c|}{$\beta$-xylosidase } & \multicolumn{2}{|c|}{$\alpha$-L-arabinofuranosidase } \\
\hline & & Yield (\%) & Expressed activity (\%) & Yield (\%) & Expressed activity (\%) & Yield (\%) & Expressed activity (\%) \\
\hline 4 & 78.1 & 79.8 & 26.1 & 94.3 & 100 & 85.4 & 42.5 \\
\hline 8 & 83.1 & 80.1 & 41.8 & 100 & 105.6 & 89.8 & 38.3 \\
\hline 16 & 84.3 & 81.7 & 11.2 & 100 & 61.5 & 98.2 & 23.5 \\
\hline
\end{tabular}

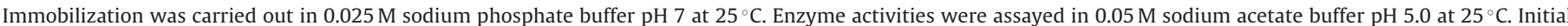
loads: xylanase-64 U; $\beta$-xylosidase-23 mU; $\alpha$-L-arabinofuranosidase-34 mU; proteins-5.3 mg.

Table 4

Post-immobilization strategies evaluated on co-immobilized xylanase, $\beta$-xylosidase and $\alpha$-L-arabinofuranosidase from P. janczewskii on Glut agarose $10 \%$ crosslinking.

\begin{tabular}{|c|c|c|c|c|c|c|}
\hline \multicolumn{4}{|l|}{ Step } & \multicolumn{3}{|c|}{ Residual activity (\%) } \\
\hline First coating & Sodium borohydride reduction & Second coating & Sodium borohydride reduction & Xylanase & $\beta$-xylosidase & $\alpha$-L-arabinofuranosidase \\
\hline PEI & - & - & - & 0 & 0 & 0 \\
\hline Dextran & + & - & - & 66.9 & 57.0 & 55.5 \\
\hline \multirow[t]{3}{*}{ Glutaraldehyde } & - & - & - & 39.6 & 21.7 & 47.8 \\
\hline & + & - & - & 33.0 & 7.7 & 25.9 \\
\hline & - & Dextran & + & 15.8 & 7.4 & 10.9 \\
\hline
\end{tabular}

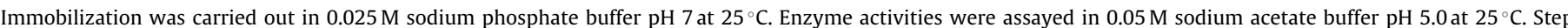
present $(+)$ or absent $(-)$.

a In relation to the expressed activities of the derivative prepared by $8 \mathrm{~h}$ incubation (Table 3 ).

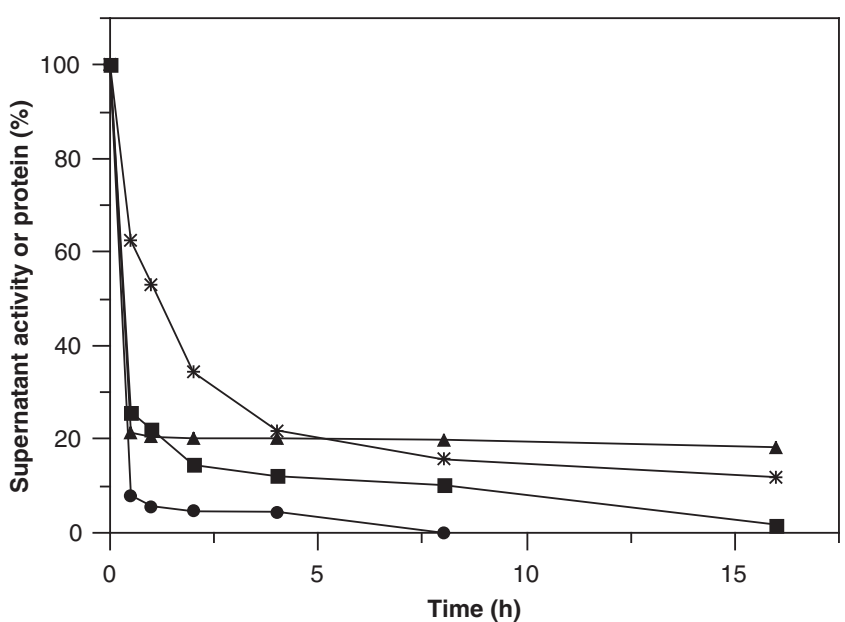

Fig. 2. Time-course of total protein, xylanase, $\beta$-xylosidase and $\alpha$ arabinofuranosidase from $P$. janczewskii co-immobilization on Glut agarose $10 \%$ crosslinking. Immobilization was carried out in $0.025 \mathrm{M}$ sodium phosphate buffer $\mathrm{pH} 7.0$ at $25^{\circ} \mathrm{C}$. Enzymatic activities were assayed in $0.05 \mathrm{M}$ sodium acetate buffer pH 5.0 at $25^{\circ} \mathrm{C}$. Initial protein $(5.3 \mathrm{mg}$ ) and activities (xylanase-64 $\mathrm{U}$; $\beta$-xylosidase-23 mU; $\alpha$-L-arabinofuranosidase-34 mU) in the supernatant were

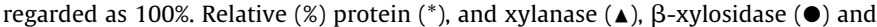
$\alpha$-L-arabinofuranosidase ( $\mathbf{\square})$ activities.

10 , a required condition for optimal immobilization in this support [21]. In the case of heterofunctional amino-glyoxyl and aminoepoxide supports (not shown) the enzymes were not immobilized, remaining in the supernatant even after $\mathrm{pH}$ increase or long-term incubation.

Considering the previous results, a comparison between the immobilization on MANAE and $0.5 \%(\mathrm{w} / \mathrm{v})$ glutaraldehyde (further called Glut agarose) prepared with different agarose beads, i.e., 4 , 6 and $10 \%$ of crosslinking, was carried out (Table 2). The expressed activity gradually increased by increasing the agarose crosslinking in the Glut derivative, whereas in the MANAE derivative the expressed activity decreased by increasing agarose crosslinking from 4 to 6 or $10 \%$. The low crosslinking level in the $4 \mathrm{BCL}$ agarose results in larger pores, which contain higher concentration of reactive groups for the co-immobilization of the enzymes

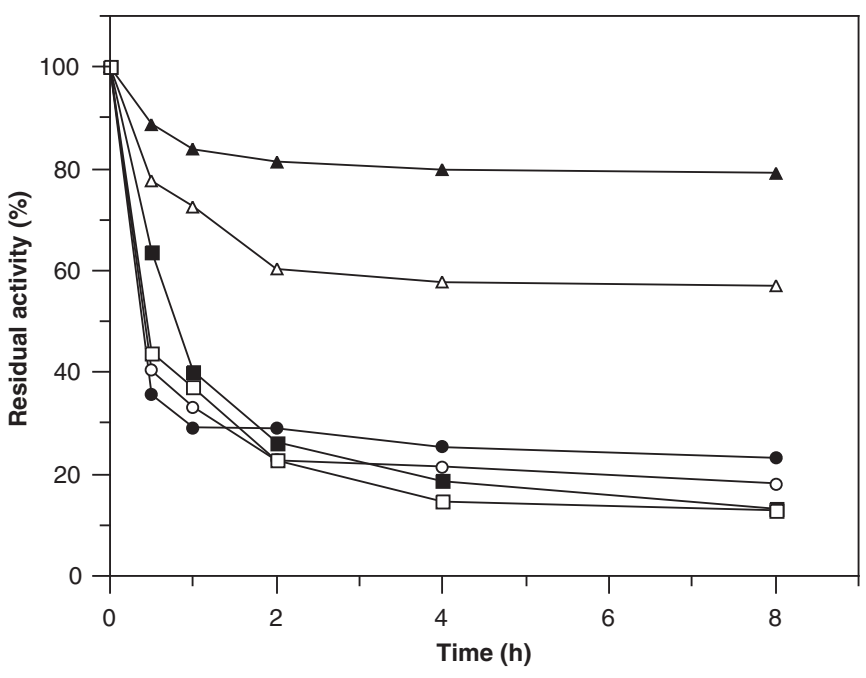

Fig. 3. Thermostability of xylanase, $\beta$-xylosidase and $\alpha$-L-arabinofuranosidase from P. janczewskii co-immobilized on MANAE-Glut derivative coated with MW 6000 and 40,000 dextrans (completely oxidized). Incubation was carried in $0.05 \mathrm{M}$ sodium phosphate buffer $\mathrm{pH} 7.0$ at $50^{\circ} \mathrm{C}$. Enzymatic activities were assayed in $0.05 \mathrm{M}$ sodium acetate buffer pH 5.0 at $25^{\circ} \mathrm{C}$. Initial activities were regarded as $100 \%$. Full symbols: derivative coated with dextran MW 6000. Empty symbols: derivative coated with dextran MW 40,000. Residual (\%) xylanase ( $\mathbf{\Lambda}), \beta$-xylosidase ( $)$ and $\alpha$-Larabinofuranosidase ( $\mathbf{\square})$ activities.

in the MANAE support. The higher quantity of weak ionic interactions were not enough to distort enzyme structure resulting in the higher expressed activities. In opposition, the lower degree of derivatization with glutaraldehyde and the consequent fewer covalent bonds in the $10 \mathrm{BCL}$ agarose resulted in less distortion to enzyme structures and consequent higher expressed activities. The Glut derivative using $10 \%$ cross-linked agarose was that which resulted in the highest expressed activity levels, corresponding to $26.1,100$ and $42.5 \%$ for the xylanase, $\beta$-xylosidase and $\alpha$-Larabinofuranosidase, respectively.

Based on previous observations, immobilization on the Glut support was followed by measuring the enzyme activities and protein in the supernatant during $16 \mathrm{~h}$ (Fig. 2). The enzymes were quickly immobilized on the support, i.e., after $30 \mathrm{~min}$ most of the enzyme 


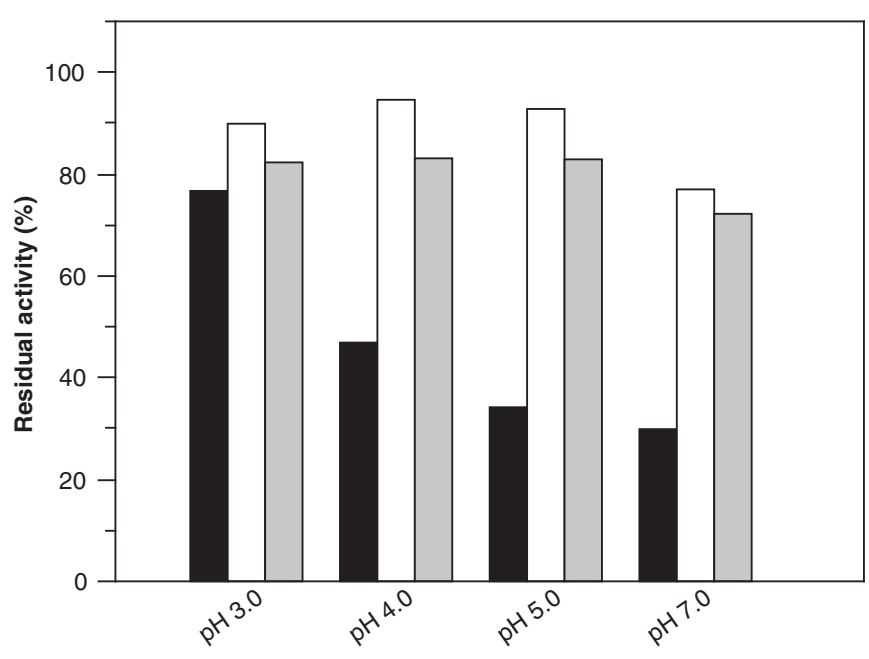

Fig. 4. Stability in different $\mathrm{pH}$ of the xylanase from P. janczewskii immobilized on Glut derivative coated with dextran MW 6000 at different degrees of oxidation. Incubation was carried for $4 \mathrm{~h}$ in $0.05 \mathrm{M}$ glycine $\mathrm{HCl}$ buffer $\mathrm{pH} 3.0,0.05 \mathrm{M}$ sodium acetate buffer $\mathrm{pH} 4.0$ and 5.0 , and $0.05 \mathrm{M}$ sodium phosphate buffer $\mathrm{pH} 7.0$, at $50^{\circ} \mathrm{C}$. Enzymatic activity was assayed in $0.05 \mathrm{M}$ sodium acetate buffer $\mathrm{pH} 5.0$ at $25^{\circ} \mathrm{C}$. Initial activities before incubation were regarded as $100 \%$. Residual (\%) activity in the derivatives coated with dextran at 20 (black), 40 (white), and 100\% (grey) degree of oxidation.

Table 5

Xylanase, $\beta$-xylosidase and $\alpha$-L-arabinofuranosidase from P. janczewskii on Glut derivative coated with dextrans of different MW and degrees of oxidation.

\begin{tabular}{lllll}
\hline MW (Da) & DO (\%) & \multicolumn{2}{l}{ Expressed activity $(\%)$} \\
\cline { 3 - 5 } & & Xylanase & $\beta$-xylosidase & $\alpha$-L-arabinofuranosidase \\
\hline 6000 & 100 & 53.5 & 41.7 & 26.4 \\
40,000 & 100 & 66.9 & 57.0 & 55.5 \\
100,000 & 100 & 8.8 & 10.2 & 24.3 \\
6000 & 20 & 35 & 31.8 & 14.8 \\
& 40 & 58.8 & 58.7 & 60.4 \\
\hline
\end{tabular}

Enzyme activities were assayed in $0.05 \mathrm{M}$ sodium acetate buffer $\mathrm{pH} 5.0$ at $25^{\circ} \mathrm{C}$. MW-molecular weight; DO-degree of oxidation.

activities had disappeared from the supernatant. After this period, immobilization proceeded at lower rate, with exception of the xylanase whose activity remained in the supernatant $(\approx 20 \%)$ for the subsequent period. Immobilization of proteins also proceeded at lower rate and after $16 \mathrm{~h}, 20 \%$ of the proteins still remained in the supernatant.

In sequence, three derivatives were prepared by carrying out immobilization for 4,8 and $16 \mathrm{~h}$ in order to verify the enzyme activities in the derivatives obtained after these three immobilization periods (Table 3). As previously observed in Fig. 2, immobilization yield in relation to protein and enzymatic activities increased by increasing the immobilization period, nevertheless the best result in terms of expressed activities was obtained with the derivative prepared by proceeding immobilization during $8 \mathrm{~h}$ (Table 3). These results indicated that enzyme-support reaction for more prolonged periods may be causing distortion of the enzyme structures, resulting in activity loss. Thus, the selected support for the co-immobilization of the xylanase, $\beta$-xylosidase and $\alpha$-L-arabinofuranosidase from $P$. janczewskii was agarose $10 \%$ crosslinking activated with MANAE cross-linked with $0.5 \%(\mathrm{v} / \mathrm{v})$ glutaraldehyde and by carrying out immobilization at $\mathrm{pH} 7.0$ for $8 \mathrm{~h}$.

In order to obtain covalent bonds from Schiff base formed between protein lysines and aldehyde groups of glutaraldehyde, the support was incubated in $\mathrm{pH} 8.5$ and reduced with (a)
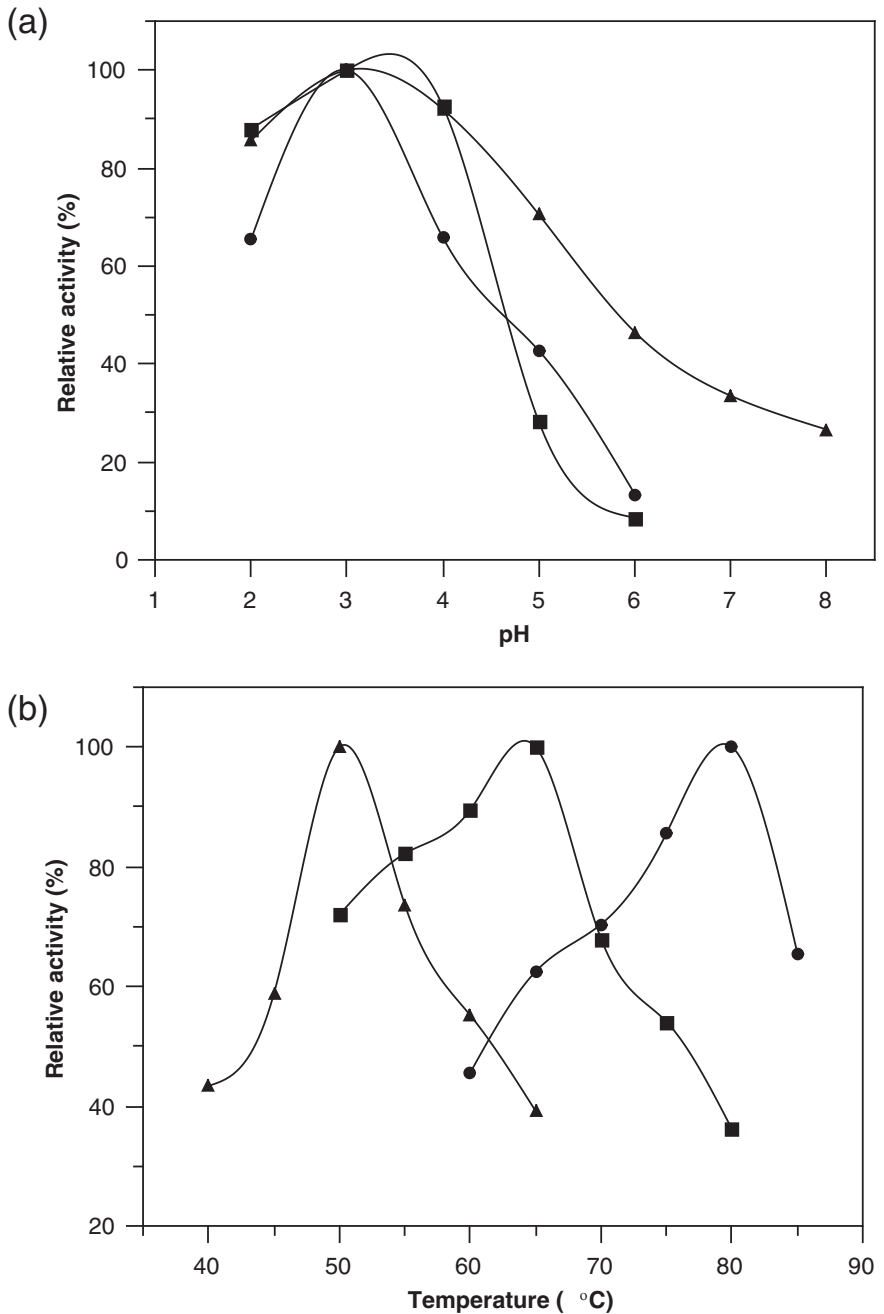

Fig. 5. Influence of $\mathrm{pH}(\mathrm{a})$ and temperature (b) on the activity of xylanase, $\beta$ xylosidase and $\alpha$-L-arabinofuranosidase from $P$. janczewskii co-immobilized on Glut derivative coated with dextran MW 6000 at $40 \%$ degree of oxidation. (a) Enzymatic activities were assayed at $25^{\circ} \mathrm{C}$ in $0.05 \mathrm{M}$ glycine- $\mathrm{HCl}$ buffer $\mathrm{pH} 2.0$ and $3.0,0.05 \mathrm{M}$ sodium acetate buffer $\mathrm{pH} 4.0$ and $5.0,0.05 \mathrm{M}$ sodium phosphate buffer $\mathrm{pH} 6.2$ and 7.0 and $0.05 \mathrm{M}$ Tris- $\mathrm{HCl}$ buffer $\mathrm{pH}$ 8.0. (b) Enzymatic activities were assayed $0.05 \mathrm{M}$ sodium acetate buffer $\mathrm{pH}$ 4.0. Relative (\%) xylanase ( $\boldsymbol{\Delta}), \beta$-xylosidase $(\bullet)$ and $\alpha$-Larabinofuranosidase ( $\mathbf{\square})$ activities.

sodium borohydride. The $\mathrm{pH}$ increase and reduction in itself negatively influenced the enzymatic activities, i.e., after the procedure, xylanase and $\beta$-xylosidase activities were 50 and $90 \%$ reduced, respectively, and no $\alpha$-L-arabinofuranosidase activity was detected on the support. Due to these results, the non-reduced Glut derivative was submitted to post-immobilization techniques (Table 4NULL, i.e., coating with PEI or dextran-aldehyde (and further reduced), and it was also submitted to a second round of cross-linking with glutaraldehyde (further reduced or not). Coating with the ionic polymer PEI had a strong negative influence and the three enzyme activities were totally depleted from the biocatalyst. Dextran-aldehyde coating and the maintenance of $\mathrm{pH} 7.0$ during borohydride reduction resulted in residual activity corresponded to $66.9,57.0$ and $55.5 \%$ of those previously observed for the xylanase, $\beta$-xylosidase and $\alpha$-arabinofuranosidase, respectively. When the derivative was submitted to a second round of glutaraldehyde crosslinking it presented residual activity of 39.6, 21.7 and $47.8 \%$ before, and 33.0, 7.7 and $25.9 \%$ after borohydride reduction, for the xylanase, $\beta$-xylosidase and $\alpha$-L-arabinofuranosidase, respectively. If this latter derivative was coated with dextran-aldehyde and then reduced, the residual activity was even lower, corre- 


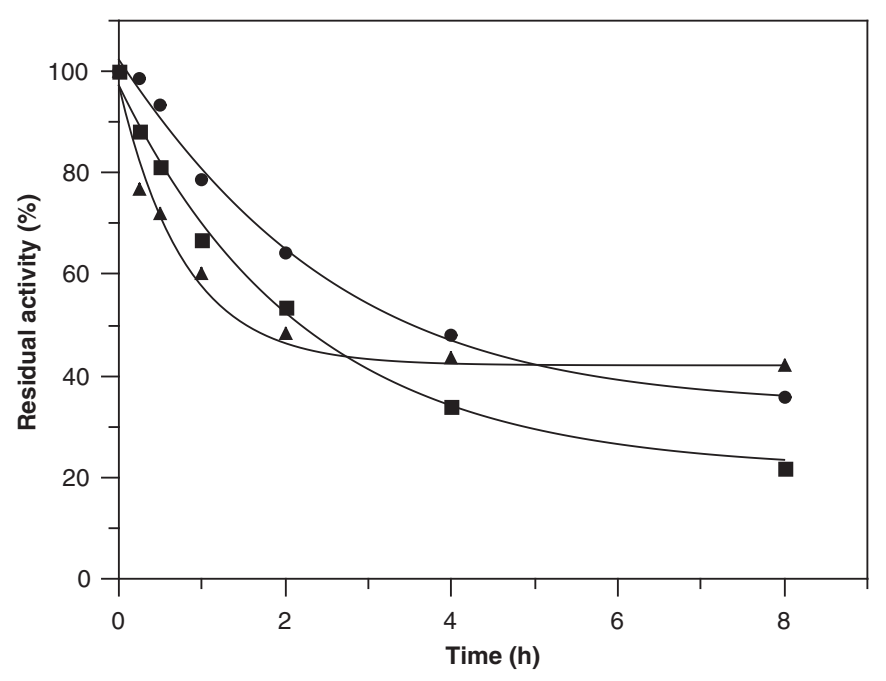

Fig. 6. Thermostability of xylanase, $\beta$-xylosidase and $\alpha$-L-arabinofuranosidase from P. janczewskii co-immobilized on Glut derivative coated with dextran MW 6000 at $40 \%$ degree of oxidation. Incubation was carried out in $0.05 \mathrm{M}$ glycine $\mathrm{HCl}$ buffer $\mathrm{pH} 3.0$ at $50^{\circ} \mathrm{C}$ for the $\beta$-xylosidase and $\alpha$-L-arabinofuranosidase, and at $80^{\circ} \mathrm{C}$ for the xylanase. Enzymatic activities were assayed in $0.05 \mathrm{M}$ sodium acetate buffer $\mathrm{pH}$ 4.0 at $25{ }^{\circ} \mathrm{C}$. Initial enzyme activities were regarded as $100 \%$. Residual (\%) xylanase $(\boldsymbol{\Lambda}), \beta$-xylosidase $(\bullet)$ and $\alpha$-L-arabinofuranosidase ( $\boldsymbol{\square})$ activities.

Table 6

Hydrolysis of wheat and oat spelt arabinoxylans by multienzymatic derivative of xylanolytic enzymes from $P$. janczewskii.

\begin{tabular}{lll}
\hline \multirow{2}{*}{ Time (h) } & \multicolumn{2}{l}{ Xylose yield (\%) } \\
\cline { 2 - 3 } & WAX & OSX \\
\hline 0.25 & 0.8 & 1.2 \\
0.5 & 1.4 & 1.9 \\
1 & 2.3 & 2.9 \\
2 & 5.0 & 5.8 \\
4 & 9.2 & 9.5 \\
8 & 16.9 & 15.1 \\
24 & 28.9 & 26.8 \\
48 & 41.0 & 37.4 \\
72 & 43.5 & 42.8 \\
\hline
\end{tabular}

Hydrolysis was carried out by incubating $0.05 \mathrm{~g}$ of Glut derivative coated with dextran MW 6000 at $40 \%$ degree of oxidation with $10 \mathrm{~mL}$ of $0.5 \%$ (w/v) substrate prepared in $0.05 \mathrm{M}$ sodium acetate buffer $\mathrm{pH} 4.0$ at $40^{\circ} \mathrm{C}$. WAX-wheat arabinoxylan; OSX-oat spelt xylan.

sponding to $15.8,7.4$ and $10.9 \%$ for the xylanase, $\beta$-xylosidase and $\alpha$-L-arabinofuranosidase, respectively.

When the Glut derivative coated with dextran (and reduced) was incubated in $0.005 \mathrm{M}$ sodium phosphate buffer $\mathrm{pH} 7.0$ containing high salt concentration $(0.5 \mathrm{M})$, no enzyme activity was verified in the supernatant after $1 \mathrm{~h}$ incubation, indicating that the enzymes were covalently immobilized in the support. The proposed mechanism of enzyme immobilization on glutaraldehyde as a bifunctional support involves initial immobilization occurring by physical adsorption due to the presence of primary amino groups and then the covalent immobilization rapidly occurs through the aldehyde portion of glutaraldehyde [34]. The use of neutral $\mathrm{pH}$ and completely oxidized aldehyde-dextran for coating the derivative surface not only preserved the enzyme activities during the reduction but may also provide rigidification of the enzyme structures due to stronger attachment of the enzymes to the support via covalent bonds. It may have the additional advantage of preventing subunit dissociation of enzymes [35], specially considering some xylanolytic enzymes, mainly $\beta$-xylosidases, which may be multimeric enzymes as cited by [31].

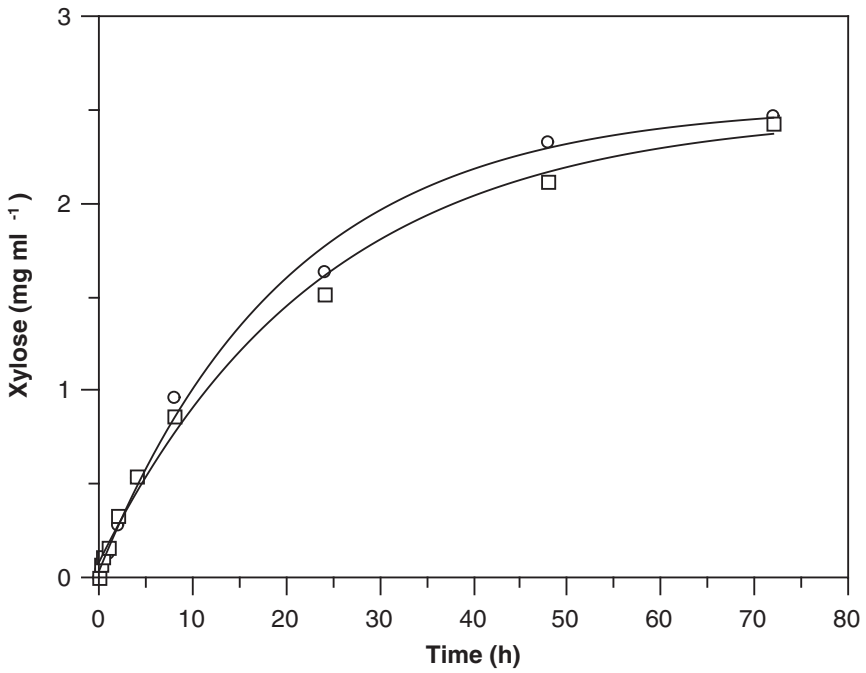

Fig. 7. Hydrolysis of wheat and oat spelt arabinoxylans by multienzymatic derivative of xylanolytic enzymes from $P$. janczewskii. Hydrolysis was carried out by incubating $0.05 \mathrm{~g}$ of Glut derivative coated with dextran MW 6000 at $40 \%$ degree of oxidation with $10 \mathrm{~mL}$ of $0.5 \%(\mathrm{w} / \mathrm{v})$ substrate prepared in $0.05 \mathrm{M}$ sodium acetate buffer $\mathrm{pH} 4.0$ at $40^{\circ} \mathrm{C}$. Xylose released $(\mathrm{mg} / \mathrm{mL})$ from oat spelt $(\square)$ and wheat $(\bigcirc)$ arabinoxylans.

In the subsequent step, dextrans of different MW (6000 40,000 and $100,000 \mathrm{Da} ; 100 \%$ degree of oxidation) were evaluated for coating the Glut derivative in order to improve enzyme activity and stabilization (Table 5). Coating the derivative with dextran MW 100,000 negatively influenced the immobilized enzymes and their activities were greatly reduced. Coating with dextran MW 6000 resulted in similar xylanase and $\beta$-xylosidase activities and half of the $\alpha$-L-arabinofuranosidase activity was observed in relation to the derivative coated with dextran MW 40,000. A previous stability study, however, demonstrated that the xylanase was more thermostable in the derivative coated with dextran MW 6000 than with dextran MW 40,000 (as further presented). In this sense, derivatives coated with dextran MW 6000 at 20 and $40 \%$ degree of oxidation (DO) were prepared and the expressed activities were compared to those from the derivative coated with the completely oxidized dextran. Among them, the lowest enzyme levels were observed in the derivative coated with dextran at $20 \%$ DO. Similar levels of xylanase and $\beta$-xylosidase were observed in the derivatives coated with dextrans at 40 and $100 \%$ DO, while the $\alpha$-L-arabinofuranosidase activity was substantially higher in the derivative coated with dextran at 40\% DO (Table 5).

\subsection{Derivative characterization}

After selecting the most adequate support and optimizing immobilization conditions, the stability of the immobilized enzymes in the Glut derivative coated with dextrans MW 6000 and 40,000 Da (completely oxidized) was initially evaluated (Fig. 3). The immobilized xylanase was highly stabilized, retaining $80 \%$ of activity in the case of the derivative coated with dextran MW 6000, and around $60 \%$ in the derivative coated with dextran MW 40,000. Similar activity was observed even after $24 \mathrm{~h}$ incubation (shown up to $8 \mathrm{~h}$ ). The $\beta$-xylosidase coated with dextran MW 6000 was only a little more stable than that coated with dextran 40,000; while for the $\alpha$-L-arabinofuranosidase no differences were observed.

When the stability of the xylanase in the derivatives coated with dextran MW 6000 at different DO was evaluated at different $\mathrm{pH}$ and $50^{\circ} \mathrm{C}$ (Fig. 4), it was observed that coating the biocatalyst surface with this polymer stabilized the enzymes in all pH. Among the 
dextrans oxidized at different degrees, the derivative coated with dextran at $20 \%$ DO presented the lowest stability, intermediate levels were verified with dextran at 100\% DO and the highest stability was observed with the $40 \% \mathrm{DO}$, especially in the $\mathrm{pH}$ range from 3.0 to 5.0 , in which more than $85 \%$ of the activity was retained.

Dextran coating as a post-immobilization technique has been widely used in enzyme technology for many different enzymes. When dextran at low degree of oxidation is used only some covalent attachments are formed between enzyme and the polymer, and the residual sugar chains remain attached rendering non-natural and large sugar moiety for the enzyme, i.e., the chemical glycosylation of a protein [36]. On the other hand, when the dextran is highly oxidized, it results in the formation of many covalent attachments between enzyme and support rigidifying enzyme structure, improving stabilization with consequent thermostabilization [25]. In this sense, some stabilization was achieved by glycosylation of the enzymes as observed for the xylanase from $P$. janczewskii, although it was not stabilized in a wide $\mathrm{pH}$ range. Additional covalent attachments rendered more stability to the enzyme at different $\mathrm{pH}$, but when excessive it results in loss of activity as previously observed in Table 5 . Thus, the best results were obtained with partially oxidized dextran, which corresponds to a mix of both glycosylation and an intermediate level of covalent attachments, rendering the highest stabilization to the co-immobilized enzymes.

Considering the stability of the immobilized xylanase in different $\mathrm{pH}$ and also that the derivative coated with dextran at 40\% DO expressed good levels of the three enzyme activities, the derivative coated with dextran MW 6000 at $40 \%$ DO was the most promising, being further characterized and applied for arabinoxylans hydrolysis.

When the enzymatic reactions were carried out at different conditions, the immobilized xylanase and $\alpha$-L-arabinofuranosidase presented optimum activity in $\mathrm{pH}$ between 2.0 and 4.0, and the $\beta$-xylosidase in $\mathrm{pH} 3.0$ (Fig. 5a). The immobilized xylanase, $\alpha$-Larabinofuranosidase and $\beta$-xylosidase presented optimum activity at 50,65 and $80^{\circ} \mathrm{C}$, respectively (Fig. 5b). A shift in the $\mathrm{pH}$ for optimum activity is observed since the free xylanase presented optimum activity at pH 5.0 and both free $\beta$-xylosidase and $\alpha$-Larabinofuranosidase were optimally active at $\mathrm{pH}$ 4.0. The optimum temperature of the xylanase was similar to that observed for the free-enzyme, while for the $\alpha$-L-arabinofuranosidase and $\beta$ xylosidase the optimum temperature was increased by $5{ }^{\circ} \mathrm{C}$ in relation to those previously observed for the free enzymes $[28,29]$.

The xylanase was highly thermostable retaining 83.1 and $70 \%$ of activity even after $24 \mathrm{~h}$ incubation at 60 and $70^{\circ} \mathrm{C}$, respectively (not shown). At $80^{\circ} \mathrm{C}$, its half-life was $1.7 \mathrm{~h}$ (Fig. 6). The $\beta$-xylosidase and the $\alpha$-L-arabinofuranosidase were very stable up to $40{ }^{\circ} \mathrm{C}$, retaining 53 and $100 \%$ of the activity after $24 \mathrm{~h}$ incubation (not shown). At $50^{\circ} \mathrm{C}$, the half-lives of the $\beta$-xylosidase and $\alpha$-L-arabinofuranosidase were 2.3 and $3.8 \mathrm{~h}$ (Fig. 6). The immobilized $\alpha$-L-arabinofuranosidase is therefore 23 -fold stabilized in relation to its free counterpart [29]. The higher thermostability of the xylanase may be associated to its possible monomeric structure and lower MW that resulted in more attachments to the support and a more adequate coating by the dextran.

\subsection{Hydrolysis of arabinoxylans}

The synergistic action of xylanolytic enzymes, divided into homeosynergy, occurring between main-chain cleaving enzymes, and heterosynergy, occurring between main-chain cleaving and debranching enzymes, has been reported by using free- [37] and at a lesser extent by using immobilized enzymes [8]. In this hydrolysis study a low viscosity wheat arabinoxylan (WAX) and oat spelt xylan (OSX) were used. WAX is a highly arabinosylated polymer containing $41 \%$ arabinose and $59 \%$ xylose residues, accord-
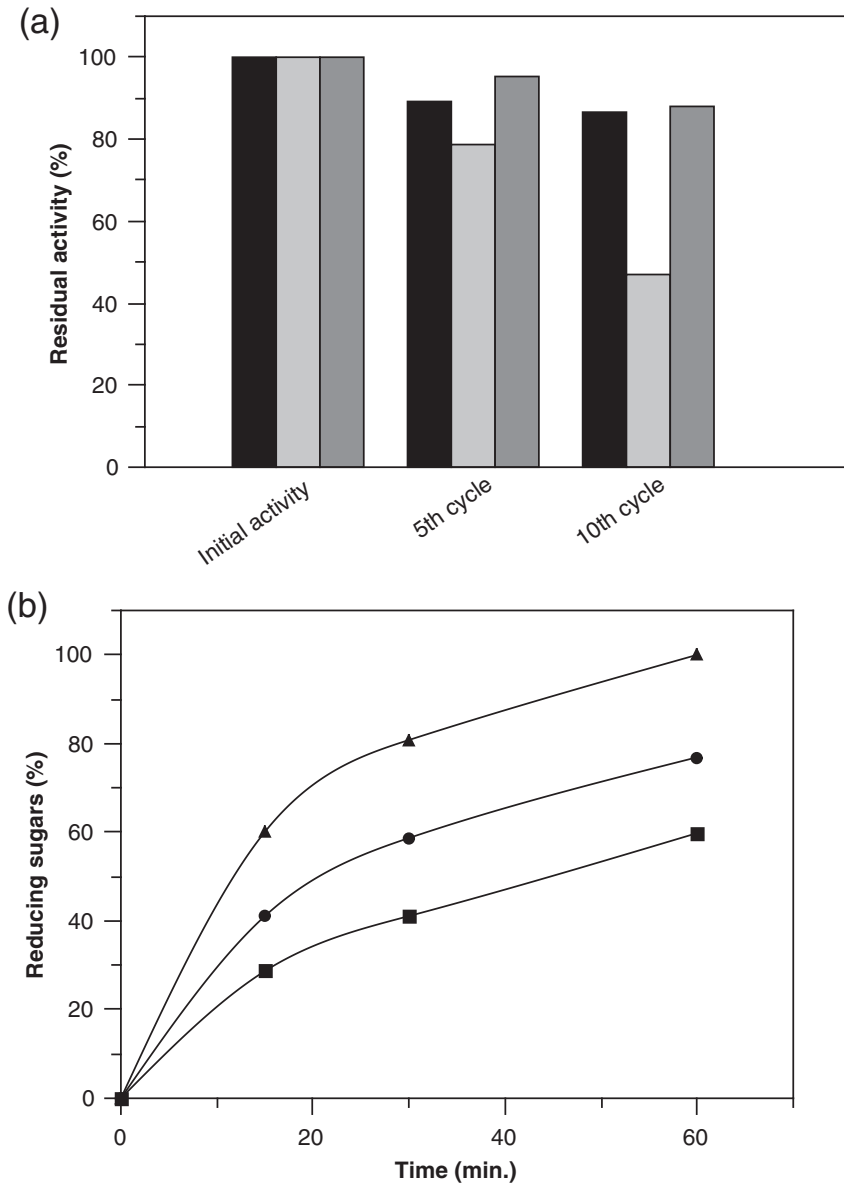

Fig. 8. Operational stability (a) and product release (b) from multienzymatic derivative of xylanolytic enzymes from $P$. janczewskii. Successive hydrolysis $1 \mathrm{~h}$-cycles were carried out by incubating $0.05 \mathrm{~g}$ of Glut derivative coated with dextran MW 6000 at $40 \%$ degree of oxidation with $10 \mathrm{~mL}$ of $0.5 \%$ wheat arabinoxylan prepared in $0.05 \mathrm{M}$ sodium acetate buffer $\mathrm{pH} 4.0$ at $40^{\circ} \mathrm{C}$. (a) Enzymatic activities were assayed in $0.05 \mathrm{M}$ sodium acetate buffer $\mathrm{pH} 4.0$ at $25^{\circ} \mathrm{C}$. Enzymatic activities before the first cycle were regarded as $100 \%$. Residual (\%) xylanase (black), $\beta$-xylosidase (ligh grey) and $\alpha$-L-arabinofuranosidase (dark grey) activities after five and ten consecutive cycles. (b) Reducing sugars (\%) released from the first ( $\mathbf{\Delta})$, fifth ( $)$ and tenth (ם) cycles.

ing to the supplier. OSX holds a complex structure containing $81.4 \%$ xylose, $9.7 \%$ arabinose, $3.4 \%$ glucose, $1.2 \%$ galactose and $4.3 \%$ uronic acid residues [38]. The presence of substituents intensely limits the action of endo-xylanase, hampering the complete degradation of the polymers into their monomers. The functionality of the multienzymatic derivative was evaluated by hydrolyzing these substrates in $\mathrm{pH} 4.0$ at $40^{\circ} \mathrm{C}$ during $72 \mathrm{~h}$ (Fig. 7). As previously observed, at these conditions the xylanase and the $\alpha$-L-arabinofuranosidase were very active, and the $\beta$-xylosidase operate with $65 \%$ of its maximum activity; at this temperature the enzymes do not operate with maximum activity, nevertheless, they present high stability to operate for prolonged cycles. The prepared biocatalyst was active and the similar hydrolysis profiles revealed that they equally degraded both substrates, independent of structure and composition. After $8 \mathrm{~h}$, the reaction velocity is reduced probably due to the inhibitory effect of xylose or arabinose on enzyme activities since the enzymes were stable in the reaction conditions. The maximum xylose yield verified after $72 \mathrm{~h}$ corresponded to 43.5 and $42.8 \%$ for WAX and OSX, respectively (Table 6).

The application of a biocatalyst in industry requires the stability of immobilized enzymes through many operational cycles. After consecutive cycles of wheat arabinoxylan hydrolysis, the 
xylanase and the $\alpha$-L-arabinofuranosidase were very stable retaining 86.6 and $88.0 \%$ of the activity even after 10 reuse cycles. The $\beta$-xylosidase activity decreased to 78.7 and $47 \%$ after five and ten cycles, respectively (Fig. 8a). The product release decreased to 80 and $60 \%$ after five and ten cycles, respectively, that may be mainly related to the reduction in the $\beta$-xylosidase activity during the cycles (Fig. 8b).

\section{Conclusions}

The simultaneous co-immobilization of the crude xylanase, $\beta$ xylosidase and $\alpha$-L-arabinofuranosidase from $P$.janczewskii was not such a simple procedure, but by adequately selecting the support and by optimizing parameters such as agarose cross-linking and immobilization period, the amount of each enzyme in the derivative can be considerably increased, allowing the preparation of a multienzymatic biocatalyst acting cooperatively in the complete degradation of complex substrates. By selecting conditions, the expressed activity of the xylanase, the most difficult enzyme to be immobilized, in the glutaraldehyde derivative can be two-fold higher than initially verified. By optimizing the dextran coating, the activity and the stability of the enzymes could also be substantially increased. The mildly activated glutaraldehyde derivative coated with low molecular weight partially oxidized dextran is the most promising, presenting interesting properties, and offering advantages over the use of free enzymes. It is possible to obtain a very stable derivative, with improved temperature, $\mathrm{pH}$ and operational stability. Furthermore, the use of this multi-enzymatic derivative leads to the direct formation of xylose monosaccharide from different arabinoxylans, therefore representing an encouraging alternative for degradation of hemicelluloses since it can be successively reused thereby reducing the need for new enzyme loads and consequently reducing the process cost.

\section{References}

[1] B. Saha, Hemicellulose bioconversion, J. Ind. Microbiol. Biotechnol. 30 (2003) 279-291, http://dx.doi.org/10.1007/s10295-003-0049-x.

[2] H.V. Scheller, P. Ulvskov, Hemicelluloses, Annu. Rev. Plant Biol. 61 (2010) 263-289, http://dx.doi.org/10.1146/annurev-arplant-042809-112315.

[3] D.B. Jordan, K. Wagschal, Properties and applications of microbial $\beta$-D-xylosidases featuring the catalytically efficient enzyme from Selenomonas ruminantium, Appl. Microbiol. Biotechnol. 86 (2010) 1647-1658, http://dx.doi.org/10.1007/s00253-010-2538-y.

[4] D. Dodd, I.K.O. Cann, Enzymatic deconstruction of xylan for biofuel production, Global Change Biol. Bioenergy 1 (2009) 2-17, http://dx.doi.org/ 10.1111/j.1757-1707.2009.01004.x.

[5] A.K.M.S. Rahman, N. Sugitani, M. Hatsu, K. Takamizawa, A role of xylanase, alpha-L-arabinofuranosidase, and xylosidase in xylan degradation, Can. J. Microbiol. 49 (2003) 58-64, http://dx.doi.org/10.1139/w02-114.

[6] R.A. Sheldon, S. van Pelt, Enzyme immobilisation in biocatalysis: why, what and how, Chem. Soc. Rev. 42 (2013) 6223-6235, http://dx.doi.org/10.1039/ c3cs60075k.

[7] L. Betancor, H. Luckarift, Co-immobilized coupled enzyme systems in biotechnology, Biotechnol. Genet. Eng. Rev. 27 (2010) 95-114, http://dx.doi. org/10.1080/02648725.2010.10648146.

[8] C.R.F. Terrasan, E.P. Cipolatti, L.T.A. Souza, R.O. Henriques, S. Moreno-Perez, W.G. Morais Junior, A.O. Chioma, J.M. Guisan, B.C. Pessela, Immobilization of plant cell wall degrading enzymes, in: R.N. Silva (Ed.), Mycol. Curr. Futur. Dev., Bentham Science Publishers B.V., 2015, pp. 276-315, http://dx.doi.org/10. 2174/97816810807411150101.

[9] M. Guerfali, I. Maalej, A. Gargouri, H. Belghith, Catalytic properties of the immobilized Talaromyces thermophilus $\beta$-xylosidase and its use for xylose and xylooligosaccharides production, J. Mol. Catal. B Enzym. 57 (2009) 242-249, http://dx.doi.org/10.1016/j.molcatb.2008.09.011.

[10] A.R.L. Damásio, B.C. Pessela, T.M. da Silva, L.H.S. Guimarães, J.A. Jorge, J.M. Guisan, et al., Co-immobilization of fungal endo-xylanase and $\alpha$-L-arabinofuranosidase in glyoxyl agarose for improved hydrolysis of arabinoxylan, J. Biochem. 154 (2013) 275-280, http://dx.doi.org/10.1093/jb/ mvt053.

[11] T. Hashimoto, Y. Nakata, Synergistic degradation of arabinoxylan with $\alpha$-L-arabinofuranosidase, xylanase and $\beta$-xylosidase from soy sauce koji mold, Aspergillus oryzae, in high salt condition, J. Biosci. Bioeng. 95 (2003) 164-169, http://dx.doi.org/10.1016/S1389-1723(03)80123-8.
[12] H.J. Vogel, A convenient growth medium for neurospora crassa, Microb. Genet. Bull. 13 (1956) 42-47

[13] C.R.F. Terrasan, B. Temer, M.C.T. Duarte, E.C. Carmona, Production of xylanolytic enzymes by Penicillium janczewskii, Bioresour. Technol. 101 (2010) 4139-4143, http://dx.doi.org/10.1016/j.biortech.2010.01.011.

[14] U.K. Laemmli, Cleavage of structural proteins during the assembly of the head of bacteriophage T4, Nature 227 (1970) 680-685, http://dx.doi.org/10.1038/ $227680 \mathrm{a} 0$.

[15] M.J. Bailey, P. Biely, K. Poutanen, Interlaboratory testing of methods for assay of xylanase activity, J. Biotechnol. 23 (1992) 257-270, http://dx.doi.org/10. 1016/0168-1656(92)90074-J.

[16] G.L. Miller, Use of dinitrosalicylic acid reagent for determination of reducing sugar, Anal. Chem. 31 (1959) 426-428, http://dx.doi.org/10.1021/ ac60147a030.

[17] H. Kersters-Hilderson, M. Claeyssens, E. Van Doorslaer, E. Saman, C.K. De Bruyne, Complex Carbohydrates Part D, vol. 83, Elsevier, 1982, http://dx.doi. org/10.1016/0076-6879(82)83062-0.

[18] R. Fernandez-Lafuente, C.M. Rosell, V. Rodriguez, C. Santana, G. Soler, A Bastida, et al., Preparation of activated supports containing low $\mathrm{pK}$ amino groups. A new tool for protein immobilization via the carboxyl coupling method, Enzyme Microb. Technol. 15 (1993) 546-550, http://dx.doi.org/10. 1016/0141-0229(93)90016-U.

[19] L. Betancor, F. López-Gallego, N. Alonso-Morales, G. Dellamora, C. Mateo, R. Fernandez-Lafuente, et al., Glutaraldehyde in protein immobilization, in: J. Guisan (Ed.), Immobil. Enzym. Cells SE-5, vol. 22, Humana Press, 2006, pp. 57-64, http://dx.doi.org/10.1007/978-1-59745-053-9_5.

[20] F. López-Gallego, L. Betancor, C. Mateo, A. Hidalgo, N. Alonso-Morales, G. Dellamora-Ortiz, et al., Enzyme stabilization by glutaraldehyde crosslinking of adsorbed proteins on aminated supports, J. Biotechnol. 119 (2005) 70-75 http://dx.doi.org/10.1016/j.jbiotec.2005.05.021.

[21] C. Mateo, J.M. Palomo, M. Fuentes, L. Betancor, V. Grazu, F. López-Gallego, et al., Glyoxyl agarose: a fully inert and hydrophilic support for immobilization and high stabilization of proteins, Enzyme Microb. Technol 39 (2006) 274-280, http://dx.doi.org/10.1016/j.enzmictec.2005.10.014.

[22] C. Mateo, B.C. Pessela, M. Fuentes, R. Torres, C. Ortiz, F. López-Gallego, et al., Very strong but reversible immobilization of enzymes on supports coated with ionic polymers, in: J. Guisan (Ed.), Immobil. Enzym. Cells SE-18, vol. 22, Humana Press, 2006, pp. 205-216, http://dx.doi.org/10.1007/978-1-59745053-9 18.

[23] C. Mateo, R. Torres, G. Fernández-Lorente, C. Ortiz, M. Fuentes, A. Hidalgo, et al., Epoxy-amino groups: a new tool for improved immobilization of proteins by the epoxy method, Biomacromolecules 4 (2003) 772-777, http:// dx.doi.org/10.1021/bm0257661.

[24] J.M. Bolivar, C. Mateo, V. Grazu, A.V. Carrascosa, B.C. Pessela, J.M. Guisan, Heterofunctional supports for the one-step purification, immobilization and stabilization of large multimeric enzymes: amino-glyoxyl versus amino-epoxy supports, Process Biochem. 45 (2010) 1692-1698, http://dx.doi. org/10.1016/j.procbio.2010.07.001.

[25] L. Betancor, F. López-Gallego, A. Hidalgo, N. Alonso-Morales, M. Fuentes, R. Fernández-Lafuente, et al., Prevention of interfacial inactivation of enzymes by coating the enzyme surface with dextran-aldehyde, J. Biotechnol. 110 (2004) 201-207, http://dx.doi.org/10.1016/j.jbiotec.2004.02.003.

[26] J.J. Sedmak, S.E. Grossberg, A rapid, sensitive, and versatile assay for protein using Coomassie brilliant blue G250, Anal. Biochem. 79 (1977) 544-552, http://dx.doi.org/10.1016/0003-2697(77)90428-6.

[27] S.M. Tauk-Tornisielo, A. Garlipp, M. Ruegger, D.S. Attili, E. Malagutti, Soilborne filamentous fungi in Brazil, J. Basic Microbiol. 45 (2005) 72-82, http://dx.doi. org/10.1002/jobm.200410418.

[28] C.R.F. Terrasan, B. Temer, C. Sarto, F.G. Silva Junior, E.C. Carmona, Xylanase and $\beta$-xylosidase from Penicillium janczewskii: production, physico-chemical properties, and application of the crude extract to pulp biobleaching, BioResources 8 (2013) 1292-1305.

[29] B. Temer, C.R.F. Terrasan, E.C. Carmona, $\alpha$-L-arabinofuranosidase from Penicillium janczewskii: production with brewers spent grain and orange waste, Afr. J. Biotechnol. 13 (2014) 1796-1806, http://dx.doi.org/10.5897/ AJB2013.13361.

[30] R.A. Sheldon, Enzyme Immobilization: the quest for optimum performance, Adv. Synth. Catal. 349 (2007) 1289-1307, http://dx.doi.org/10.1002/adsc. 200700082.

[31] A. Knob, C.R.F. Terrasan, E.C. Carmona, $\beta$-xylosidases from filamentous fungi: an overview, World J. Microbiol. Biotechnol. 26 (2010) 389-407, http://dx.doi. org/10.1007/s11274-009-0190-4.

[32] B.C. Saha, $\alpha$-l-arabinofuranosidases, Biotechnol. Adv. 18 (2000) 403-423, http://dx.doi.org/10.1016/S0734-9750(00) 00044-6.

[33] O. Barbosa, C. Ortiz, A. Berenguer-Murcia, R. Torres, R.C. Rodrigues, R. Fernandez-Lafuente, Glutaraldehyde in bio-catalysts design: a useful crosslinker and a versatile tool in enzyme immobilization, RSC Adv. 4 (2014) 1583-1600, http://dx.doi.org/10.1039/C3RA45991H.

[34] L. Betancor, F. López-Gallego, A. Hidalgo, N. Alonso-Morales, G. Dellamora-Ortiz, J.M. Guisán, et al., Preparation of a very stable immobilized biocatalyst of glucose oxidase from Aspergillus niger, J. Biotechnol. 121 (2006) 284-289, http://dx.doi.org/10.1016/j.jbiotec.2005.07.014.

[35] R. Fernandez-Lafuente, Stabilization of multimeric enzymes: strategies to prevent subunit dissociation, Enzyme Microb. Technol. 45 (2009) 405-418, http://dx.doi.org/10.1016/j.enzmictec.2009.08.009. 
[36] M.L.E. Gutarra, O. Romero, O. Abian, F.A.G. Torres, D.M.G. Freire, A.M. Castro, et al., Enzyme surface glycosylation in the solid phase: improved activity and selectivity of Candida antarctica Lipase B, ChemCatChem 3 (2011) 1902-1910, http://dx.doi.org/10.1002/cctc.201100211.

[37] J.S. Van Dyk, B.I. Pletschke, A review of lignocellulose bioconversion using enzymatic hydrolysis and synergistic cooperation between enzymes-factors affecting enzymes, conversion and synergy, Biotechnol. Adv. 30 (2012) 1458-1480, http://dx.doi.org/10.1016/j.biotechadv.2012.03.002.

[38] F.J.M. Kormelink, a. GJ. Voragen, Degradation of different [(glucurono) arabino]xylans by a combination of purified xylan-degrading enzymes, Appl. Microbiol. Biotechnol. 38 (1993) 688-695, http://dx.doi.org/10.1007/ BF00182811. 